\title{
A MAGÁNVAGYONVÉDELEM AKADÁLYAI NAPJAINKBAN
}

\section{THE PROBLEMS OF PRIVATE SECURITY NOWADAYS}

\author{
Csege Gyula ${ }^{1}$, Gáll Tamás ${ }^{2}$ \\ ${ }^{1}$ Hajdú-Bihar Megyei Rendör-fókapitányság, Cím: 4200, Magyarország, \\ Hajdúszoboszló, Bocskai Utca, 31. szám; Telefon: +0036308355939, levelezési cím: \\ gyulacsege@gmail.com \\ ${ }^{2}$ TAKATA Safety Systems Hungary Kft., Cím: 3530. Miskolc, Corvin u. 1. 10/3. \\ szám; Telefon: +0036307210469, tamas.gall@sec-tech.hu
}

\begin{abstract}
For the past period, the security challenges are increasing and in dynamically changing, which cause significant changes in the security sector. Besides the changes of the national or federal Security level, that is very important for the private sector to follow the security challenges and prepare for the new risks. After reviewing education and training level of the current private security sector, I would like to present the nowadays Hungarian private security sectors status and I will make propose to a possible and necessary changing direction.
\end{abstract}

Keywords: security, private security, training, challenges,

\section{Összefoglalás}

Az elmúlt időszak növekvő és dinamikusan változó kihívásai jelentős változásokat okoznak a biztonsági szektorban. A nemzeti vagy szövetségi biztonsági szint változása mellett igen fontos, hogy a magánbiztonsági szektor is kövesse a kihívásokat és felkészüljön a kockázatokra. A jelenlegi magánbiztonsági szektor oktatási, képzési szintjének áttekintése után be kívánjuk mutatni Magyarország személy vagyonvédelmének állapotát, valamint szükséges változási irányaira is javaslatot teszek.

Kulcsszavak: biztonság, vagyonvédelem, képzés, kihivások

\section{The personal and property security}

The personal and property protection is an important factor in population in the subjective sense of security guaranteeing. You can not make up the work of the law enforcement agencies and presence, but it's not your job. In our study, based on the legislation framework and the challenges of the era of the private security sector, outlined aspects.

\subsection{According to the legal framework for the development of security education Hungary}

The first modern-day legislation, security tasks prior to the change of regime 4/1987. (VII. 22.) MT of the Regulation on private security activity and the banning of private investigation, which for regulating the protection of private property, which is also banned in private investigation. [1]

Because of the capitalist regime after layer formation process of privatization and 
the private bodyguard came over regulation, which was the 87/1995. (VII.14.) decree enacted during that until 1 May 1998, the rules made under the passenger business, security and private detective activity, bodyguards, 1998. act. IV. of Private Detectives and Security Chamber. Act came into force was in place. Then, on July 9, 1998 entered into force on implementation of the law 24/1998 of the Interior Ministry. (VI.9.). regulation. [2]

The legislation follows the line of the 2005. CXXXIII. law rules of private security and private investigation activities.

The continuous changes in legislation / development, something dynamic crime, forensic science, and private property protection and development strategies established the National Crime Prevention Strategy, which has somewhat changed as part of the qualification private security types.

The 68/2012. (XII. 14.) Ministry of the Interior Decree on performing policing duties persons, assistant supervisors, and the private guards of training and examination for entry into force, it became necessary due to changes in training for those working in the field of private security previously. [3]

Before the publication of the Regulation as a basic qualification to operate in the field of manpower property protection seekers in the "Security Guard" names qualifications acquired, they received the "guard" and the "Bodyguard" on which skills are included.

Which it was downstream qualifications that can be acquired as the "Armed security guard," "Guard Dog", "guard dog", "Bank Watch", "Major Event Insurance 'and' CIT 'qualifications as well. [4]

From 1st September 2013, the basic qualification as a Security guard skills have been displayed, which is no longer part qualification, but appear in the official qualifications such as: Bank Watch, Event
Insurance, Guard Dog, CIT. Of course, the list of downstream qualifications should also change. The qualifications under the current regulatory set out in the Armed security guard, a guard dog, a bodyguard, a security mechanical mounting and assembly of electronic security system. [5]

The 38/1997 (VI. 27.) BM education and examination system regulating the Interior for the acquisition of personal and property qualifications first Ministerial Regulation covers. That defines the qualifications a prerequisite for obtaining the age of 18 is loaded, criminal record, incapacity, permanent domestic residence. During the training, participants had to learn in addition to basic self-defense catches the necessary legal provisions (constitutional, criminal, administrative, civil and criminal procedure), basic forensic and psychological principles, as well as the protected objects, property or personal guard, protecting the security, professional rules and methods for threat repel. The basic skills training in 300 classes have been imposed, which was divided by 180 hours of theory and 120 hours of practical occupations. [6]

The 12/1995 (VIII.18.) BM and listed in 29/1997 (IV.18.) no BM based on Security guard qualifications must be accepted as:

- universities, Faculty of Law,

- The Police Academy,

- The Police Academy faculty retraining,

- The College of Public Administration Department organized administrative system,

- The Military Academy military security and general reconnaissance earned his degree,

- police obtained a certificate in Secondary School,

- he graduated from the military higher education institutions,

- the Police Academy,

- a specialist police school, 
- a specialist border police training school,

- to enforce the sentence NCO professional training school,

- qualified as secondary military training establishment, - The dog is a leading qualification,

- the organizers of safety qualification,

- the 14/1960 (III.24.) Government Decree 6/1988 and took the (II.12.) MT Regulation on the basis policeman qualification if the applicant demonstrates that at least 3 years working security guard jobs within 10 years before the entry into force of this Regulation. [7]

Looking at the theoretical readiness review the personal and property guard training educational materials, it emerged after the political front Security guard training materials and training teaching aids law enforcement vocational schools NCO training subjects are public law enforcement, forensic and legal subjects educational tematikáinak foundations of the day.

The Act CXX of 2012. law and its implementation in caring 68/2012. Under (XII. 14.) BM property force must be aware of the changed regulatory environment, including new rights and obligations, which the Basic Law, the Criminal Code, the Civil Code, the Act on changes evolved. [8]

Since the regime established security education, we can say that a strong legal overweight. Because of that, if a guard is fresh work after the course, you may not be able to perform the tasks entrusted to it because the basic training of service parameters, that is the real "know-how" is not included. Unfortunately, in the 40 hours of practical training at either block. [9]

The training has changed due to the new Adult Education Act, which aims to accurately read the first couple of series in the act: „to live in our country people cope with the economic, cultural and technological development challenges of successfully connect to the world of work, success are to be effective in their lives, and with the help of adult learning and training in the life quality improve both, you need a professional, linguistic and supported the organization of training courses to increase, the quality of their content and their implementation to strengthen controls" [10]

\section{Security challenges}

Today, major changes noticeable in the area of security challenges. In many parts increased to a higher level of attention among areas, and get some of the less significant value. The migration crisis, mass attacks, the European Union also wants terror rising much faster and higher quality answers to the security area concerned. Easier and more popular in the private sector, the target objects in the attacks as a key building better protected. Identification of the attacks is much better prepared to protect and professionals and raising statutory framework would require.

\section{Conclusions}

In short illustrated overview wanted, how it changed the person and property protection specialist with training in Hungary and the challenges have changed over the past nearly 30 years.

It can see that in many cases the laws and links to make an exception for law enforcement personnel and the person entitled to make security activities. This direction can agree only in part, because the police did not universal private security personnel. A civil party against the benefits are the same skills or qualifications of, but the police did not provide private security professional qualifications.[11] We see a need for private security professionals a separate group, specialized in the sector 
meet the challenges of adequately trained conferred, as shall be provided with completely different tasks. The responses to the challenges private sector built up a specialized knowledge can be answered, not the adoptive or education based on a knowledge of the law enforcement.

\section{References}

[1] 4/1987. (VII. 22.) MT rendelet a vagyonvédelmi tevékenységről és a magánnyomozás tilalmáról 2016.01.05.

[2] 24/1998. (VI. 9.) BM rendelet a vállalkozás keretében végzett személy- és vagyonvédelmi, valamint a magánnyomozói tevékenység szabályairól, a Személy-, Vagyonvédelmi és Magánnyomozói Szakmai Kamaráról szóló törvény végrehajtásáról 2016.01.05.

[3] 68/2012. (XII. 14.) B.M. rendelet a rendészeti feladatokat ellátó személyek, a segédfelügyelők, valamint a személy- és vagyonőrök képzéséröl és vizsgáztatásáról 2016.01.05.

[4] 68/2012. (XII. 14.) B.M. rendelet a rendészeti feladatokat ellátó személyek, a segédfelügyelök, valamint a személy- és vagyonőrök képzéséröl és vizsgáztatásáról 2016.01.05.
[5] 68/2012. (XII. 14.) BM rendelet a rendészeti feladatokat ellátó személyek, a segédfelügyelők, valamint a személy- és vagyonörök képzéséröl és vizsgáztatásáról 2016.01.05.

[6] 38/1997. (VI. 27.) BM rendelet egyes szakmai és vizsgáztatási követelmények kiadásáról 2016.01.05.

[7] 12/1995. (VIII. 18.) BM rendelet a vállalkozás keretében végzett személy- és vagyonőri, valamint a magánnyomozói tevékenység végzéséhez szükséges szakképesítésről 2016.01.05.

[8] 2012. évi CXX. Törvény az egyes rendészeti feladatokat ellátó személyek tevékenységéről, valamint egyes törvényeknek az iskolakerülés elleni fellépést biztosító módosításáról 2016.01.05.

[9] 68/2012. (XII. 14.) BM rendelet a rendészeti feladatokat ellátó személyek, a segédfelügyelők, valamint a személy- és vagyonőrök képzéséről és vizsgáztatásáról 2016.01.05.

[10] 2013. évi LXXVII. Törvény a felnőttképzésröl 2016.01.05.

[11] Z. Rajnai, B.Puskas: Requirements of the installation of the critical informational infrastructure and its management interdisciplinary description of complex systems (ISSN: 1334-4684) (eISSN: 13344676) 13: (1) pp. 48-56. (2015) 